\title{
伝達関数を用いたゼロパワー磁気浮上制御系の解析と設計
}

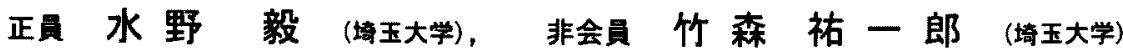

\section{A Transfer-Function Approach to the Analysis and Design of Zero Power Controllers for Magnetic Suspension System}

\author{
Takeshi MIZUNO, Member (Saitama University) \\ Yuichiro TAKEMORI, Non-member (Saitama University)
}

\begin{abstract}
A transfer function approach is applied to the analysis and design of zero power controllers for magnetic suspension systems. The general structures of controllers achieving zero power control are derived for both current- and voltage-controlled magnetic suspension systems. For the former-type system, there are two basic approaches: feeding back velocity signal and introducing a minor feedback of the integral of current. Both the approaches are applicable to the latter-type system. In addition to them, the position-sensorless approach also realizes zero power control automatically. A direct synthesis method for zero power control is developed based on the analysis. Several experiments are carried out with a single-degree-of-freedom model. The experimental results show the effectiveness of the proposed synthesis method.
\end{abstract}

キーワード：磁気軸受，磁気浮上，ゼロパワー制御，センサレス制御，伝達関数

Keywords: magnetic bearing, magnetic suspension, zero power control, sensorless control, transfer function approach

\section{1. 粕 言}

磁気浮上や磁気軸受では，目的に応じてさまざまな特徴 を持つ制御方法が開発されている。その一つにぜロパワー 制御がある。これは，バイアス磁束を承久磁石で与える磁 気浮上系において, 電磁石のコイル電流を定常的には雾に 保ち，承久磁石の吸引力だけで重量を支持する制御方法で ある、ゼロパワー磁気浮上系では，浮上に要する入力エネ ルギが定常的には零になるので，消費電力をできるだけ低 堿する必要がある宇宙用機器 ${ }^{(1)}$ (3)や無集電型磁気浮上搬送 装置(4)で利用されている，また，ゼロパワー磁気浮上系は， 電磁石から引き離す方向に一定の外力が浮上対象物に作用 すると，定常的には電磁石と浮上対象物との間のギャップ が減少するという，ユニークな特性を持っている．最近， この特性を利用して，地動外乱に対する除振性能を損なう ことなく，直動外乱に対しては高い㓮性を実現するアクテ イブ除振装置が提案され，開発が進められている(5).

ゼロパワー制御系を実現するには，これまでに，

・速度信号に基ついてフィードバック制御する(1).(2),

・コイル電流の積分值を局所フィードバックする(3) (4),

・外乱オブザーバを利用する(6)(7),

・ローパスフィルタを利用する(6),
・制御電圧の積分值を局所フィードバックする(ク, などの方法が提案されている.また，

・オブザーバを利用した変位センサレス磁気浮上 においてもゼロパワ一特性が寒現されることが指摘されて いる(8). しかしながら，ぜロパワー制御を実現するコントロ 一ラの相互関係や一般的な構造・設計法は必ずしも明らか にされていない.

著者らは, 電流出力形アンプを備えた磁気浮上系に対し て，伝達関数を用いた解析法を適用することによって，ぜ ロパワー制御を実現するコントローラの一般的な柾造を明 らかにし，さらにこの結果を踏まえて，コントローラを直 接構成していく設計法を提案している(9). 本報では, 電圧出 カ形アンプを備えた磁気浮上系を含む，より一般的な議論 を展開し，奏験によってそれらの有効性を検証する。

\section{2. 解析モデル}

本論文では，図 1 に示すような，磁気浮上において最も 基本的となる 1 自由度モデルに基づいて議論を進める. 浮 上用磁石としては，承久磁石と電磁石からなるハイブリッ ド磁石を用いている。簡単のため，浮上対象物は，ハイブ リッド磁石の吸引力の作用する方向（図では垂直方向）に 並進運動の自由度だけを持っていると仮定する。 
浮上対象物に作用する重力と承久磁石による吸引力とが つり合っている状態からの浮上祄象物の垂直方向の変位を $x$ で表す上，この系の運動方程式は次式のようになる.

$$
m \ddot{x}(t)=k_{s} x(t)+k_{i} i(t)+w(t)
$$

ここで,

$$
\begin{array}{ll}
m & : \text { 浮上対象物の質量, } \\
k_{s} & : \text { 電磁石の特性係数 (=力/変位), } \\
k_{i} & : \text { 電磁石の特性係数 (=力/電流), } \\
i & : \text { 電磁石のコイル電流, } \\
w & : \text { 浮上対象物に作用する外力(外乱). }
\end{array}
$$

電磁石の電気回路に関する方程式はつぎのようになる.

$$
L \frac{d i(t)}{d t}+R i(t)+k_{b} \dot{x}(t)=v(t)
$$

$$
\text { ここで, }
$$

$L \quad$ : 電磁石コイルの自己インダクタンス,

$R$ : 電磁石コイルの抵抗,

$k_{b}:$ 逆起電力保数,

$v$ : 電磁石コイルの端子電圧の変動分.

简単のため，初期值を零として式(1)，(2)をラプラス変換し， 整理すると次式を得る。

$$
\begin{aligned}
& X(s)=\frac{1}{t_{0}(s)}\left(b_{0} I(s)+d_{0} W(s)\right) \\
& (L s+R) I(s)+k_{b} s X(s)=V(s)
\end{aligned}
$$

ここで,

$$
t_{0}(s)=s^{2}-a_{0}, \quad a_{0}=\frac{k_{s}}{m}, \quad b_{0}=\frac{k_{i}}{m}, \quad d_{0}=\frac{1}{m} .
$$

磁気浮上系は, 電磁石を励磁するアンプによって 2 種類 に分類される.一つは, 電磁石の励磁に電流出力形のアン プを用いるもので，電流制御形磁気浮上と呼ばれる：この 場合，電磁石のコイル電流を制御入力として扱うことがで きるので，制御系は，式(3)に基ついて設計される.もう一 つは, 電生制御形磁気浮上で, 電磁石の励磁に電圧出力形 アンプを用いる．この場合には，コイルの端子電圧が制御

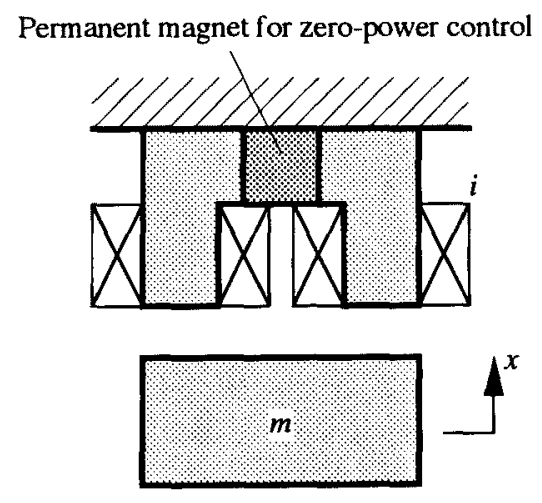

図 1 基本モテル

Fig.1. Basic model
入力となり，コイル電流は状態変数とみなされる. 制御系 は，式(3)および式(4)に基ついて設計される.

\section{3. 伝達関数を用いた解析}

ゼロパワー制御について議論するため，外乱 $w$ は一定で あるとする．このとき，w は次式のように表される.

$$
W(s)=\frac{A_{0}}{s}
$$

3.1 電流制湖形磁気浮上通常の磁気軸受では，変位セ ンサの信号に基ついて制御入力が定められる. したがって, 時不変ゲインの線形制御を実施する場合には，制御則は一 般に次式のように表すことができる.

$$
I(s)=-\frac{h(s)}{g(s)} X(s)
$$

ここで， $g(s) ， h(s)$ は互いに素な $s$ 多項式である. 本節 では，これらの多項式が閉ループ系を安定にするように， すなるち特性方程式

$$
\begin{aligned}
t_{c}(s) & =\left(s^{2}-a_{0}\right) g(s)+b_{0} h(s) \\
& =0
\end{aligned}
$$

のすべての根の実部が負になるように選ばれているとして 議論を進める。

式(6)を式(3)に代入して，整理すると

$$
I(s)=-\frac{h(s)}{t_{c}(s)} d_{0} W(s)
$$

となる．式(8)に式(5)を代入すると次式が得られる.

$$
I(s)=-\frac{h(s)}{t_{c}(s)} d_{0} \frac{A_{0}}{s}
$$

式(9)から，浮上対象物に一定外力が作用しても定常的には コイル電流が零に収束するというぜロパワー特性を実現す るには, $h(s)$ が $s$ を因子に持つ必要があることがわかる. すなわち, $h(s)$ は，

$$
h(s)=s \tilde{h}(s)
$$

$$
\tilde{h}(s): g(s) \text { と互いに素な } s \text { 多項式 }
$$

と表されることになる．この関係を図に示すと図2(a)のよ うになる，変位を時間微分すると速度になるので，

[万式 I] 速度信号に基づいてフィードバック制御する ことによってぜロパワー制御を実現できることがわかる. 式(10)を式(6)に代入した式は，次のように変形できる.

$$
\begin{aligned}
I(s) & =-\frac{s \tilde{h}(s)}{g(s)} X(s) \\
& =-\frac{1}{1+\frac{\tau}{s}} \cdot \frac{(s+\tau) \tilde{h}(s)}{g(s)} X(s)
\end{aligned}
$$


式(11)の関係は図 2(b)のように表される，図より，

[方式 I] 電流の積分值を局所フィードバックする

ことによってもぜロパワー制御を実現できることがわかる。 3.2 两圧制御型磁気浮上電圧制御形磁気浮上系では, 直接計測できる変数は，変位 $x$ と電流 $i$ であることが多い. したがって，制御則は一般に次式のように表すことができ る.

$$
\begin{aligned}
V(s) & =-M(s) X(s)-P(s) I(s) \\
& =-\frac{n(s)}{m(s)} X(s)-\frac{q(s)}{p(s)} I(s)
\end{aligned}
$$

$n(s), m(s):$ 互いに素な $s$ 多項式,

$q(s), p(s)$ : 互いに素な $s$ 多項式.

式(12)を式(4)に代入すると，次式が得られる.

$$
I(s)=-\frac{M(s)+k_{b} s}{P(s)+L s+R} X(s)
$$

ここで,

$$
\frac{M(s)+k_{b} s}{P(s)+L s+R}=\frac{h(s)}{g(s)}
$$

とおくと，式(13)は

$$
I(s)=-\frac{h(s)}{g(s)} X(s)
$$

となるので，電流制御形磁気浮上の場合と同じように考え ていくことができる(式(6)参照).

[方式 I ] を適用するため， $M(s)$ を

$$
M(s)=\frac{s \tilde{n}(s)}{m(s)}
$$

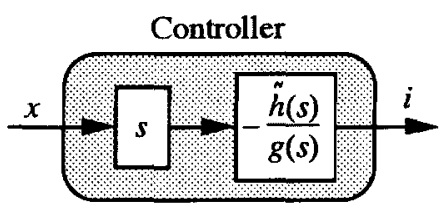

(a) Derivative feedback of displacement

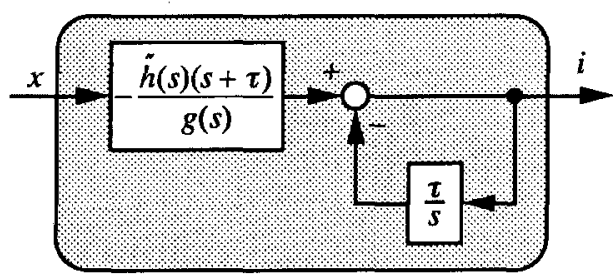

(b) Integral feedback of current

図 2 セロパワーコントローラの一般形 (電流制御形磁気浮上の場合)

Fig.2. General forms of zero-power controllers for the current-controlled magnetic suspension system. $\widetilde{n}(s): m(s)$ と互いに素な $s$ 多項式

を満たすように選ぶ。このとき，式(13)は，

$$
I(s)=-\frac{\left\{\tilde{n}(s)+k_{b} m(s)\right\} p(s)}{\{q(s)+(L s+R) p(s)\} m(s)} \cdot s X(s)
$$

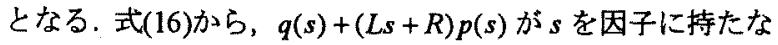
いように $q(s), p(s)$ が選ばれていれば，ゼロパワー制御が達 成されることがわかる。この場合のコントローラの構成を 図3(a)に示す，なお，フィル夕方式と呼ばれているぜロパ ワー制御系 ${ }^{(6)}$ では, ローパスフィルタの出力と元の信号との 差をとることによって，すなわち

$$
\begin{aligned}
& \left(\tilde{M}(s)-\frac{\tilde{M}(s)}{T s+1}\right) X(s)=\tilde{M}(s) \frac{T s}{T s+1} X(s) \\
& T: \text { フィルタの時定数, } \\
& \tilde{M}(s): \text { 補償器の伝達関数. }
\end{aligned}
$$

の関係を利用して、このような形の補償を実現している.

この方式のコントローラは, 図 2 で用いたブロック線図 の等価変換の公式を適用することによって，図3(b)のよう に局所積分フィードバックを利用するように変形すること ができる、さらに，電流フィードバックを用いない場合， すなわち,

$$
P(s)=0
$$

のときは，図3(c)に示すように，制御入力vの積分值を局 所フィードバックする構成とすることもできる. 電圧指令 型と呼ばれるゼロパワー制御系(7)は、このような構造を持っ ている。

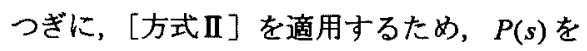

$$
P(s)=\frac{q(s)}{\widetilde{s p}(s)}
$$

$\widetilde{p}(s): q(s)$ と互いに素な $s$ 多項式

を満たすように選ぶ。式(20)を式(13)に代入するとつぎのよ うになる。

$$
I(s)=-\frac{\left\{n(s)+k_{b} s m(s)\right\} \tilde{p}(s)}{\{q(s)+s(L s+R) \tilde{p}(s)\} m(s)} \cdot s X(s)
$$

式(21)から， $m(s)$ が $s$ を因子に持たないように選ばれていれ ば、ゼロパワー制御が達成されることがわかる。このとき のコントローラの構成を図 3(d)に示す.

電王制御形磁気浮上に特有な方法として，電流だけをつ ィードバックするという方法がある.すなわち,

$$
M(s)=0
$$

とすると、式(13)はつぎのようになる.

$$
I(s)=-\frac{k_{b} s}{P(s)+L s+R} X(s)
$$

式(23)から， $P(s)+L s+R$ が $s$ を因子に持たないように $P(s)$ 
が選ばれていれば、ゼロパワー制御が達成されることがわ かる.これは，コイルに誘導される逆起電力を利用した変 位センサレス（セルフセンシング）磁気浮上系がゼロパワ 一特性を持つ(8)ということを示唆している.このときのコン トローラの構成を図 $3(\mathrm{e}) に$ 示す.この場合には，コントロ ーラに構造的な制約は必要ない.

\section{4. 制御系設計}

前章までの議論に基づいて，ゼロパワー制御を実現する コントローラを直接構成していく設計方法を示す。

4.1 雷流制件形碰気浮上式(6),(10)から，目的とするコ ントローラは，つぎのように表すことができる.

$$
I(s)=-\frac{s \widetilde{h}(s)}{g(s)} X(s)
$$

コントローラの伝達開数をプロパーな有理関数から選ぶ場 合，コントローラの次数 ( $g(s)$ の次数) を $r$ とすると，閉 ループ系の特性多項式の次数は $(r+2)$ ，コントローラで自 由に設定できるパラメータの個数は $2 r$ となる.したがって， 閉ループ系の極を任意に配置するためには，

$$
2 r \geq r+2 \quad \therefore r \geq 2 \text {, }
$$

すなわち，2次以上の次数を持つコントローラが必要とな る、最も低次のものを用いる場合，式(24)はつぎのように表 される。

$$
I(s)=-\frac{s\left(h_{2} s+h_{1}\right)}{s^{2}+g_{1} s+g_{0}} X(s)
$$

式(7), (26)から，次式が得られる.

$$
\begin{aligned}
t_{c}(s) & =s^{4}+g_{1} s^{3}+\left(-a_{0}+g_{0}+b_{0} h_{2}\right) s^{2} \\
& +\left(-a_{0} g_{1}+b_{0} h_{1}\right) s-a_{0} g_{0}
\end{aligned}
$$

配置したい極を指定する多項式 $t_{d}(s)$ を次のようにおく，

$$
t_{d}(s)=\left(s^{2}+2 \zeta_{1} \omega_{1} s+\omega_{1}{ }^{2}\right)\left(s^{2}+2 \zeta_{2} \omega_{2} s+\omega_{2}{ }^{2}\right)
$$

式(27)と式(28)とを比較すると，ゼロパワー制御を達成する と同時に，望ましい極配置を塞現するコントローラの係数 が求められる.

4.2 電圧制御形磁気浮上電圧制御形磁気浮上系の場合 には，変位フィードバックと電流フィードバックの組み合 わせ方によっていろいろな実現方法が可能となる．ここで は，変位フィードバックだけを用いる場合について耣じる。 式(12)，(16)，(19)から，コントローラは，つぎのように表 すことができる

$$
V(s)=-\frac{\tilde{s}(s)}{m(s)} X(s)
$$

コントローラの伝達関数をプロパーな有理関数から選ぶ場 合，コントローラの次数 $(m(s)$ の次数 $)$ をとすると，閉 ループ系の特性多項式の次数は $(r+3)$, コントローラで自由 に設定できるパラメータの個数は $2 r$ となる．したがって，

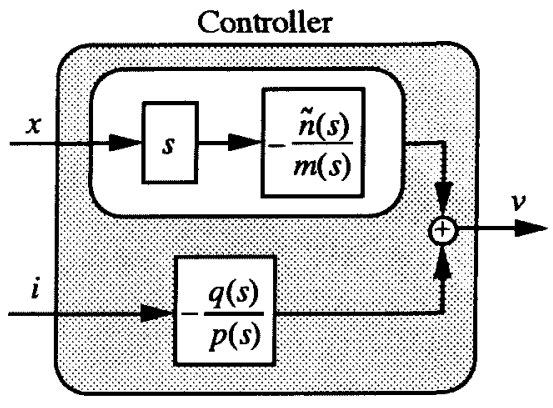

(a) Derivative feedback of displacement

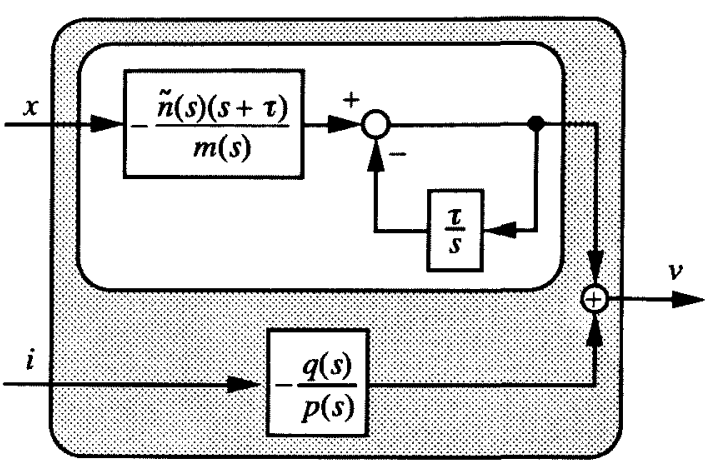

(b) Local integral feedback

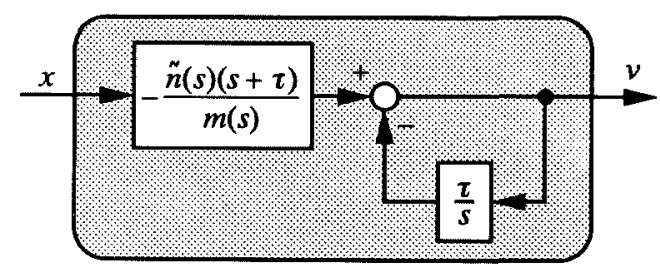

(c) Integral feedback of voltage

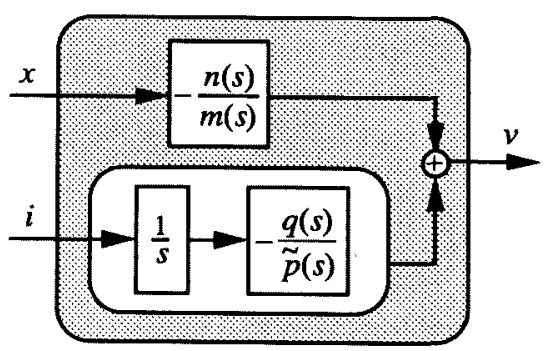

(d) Integral feedback of current

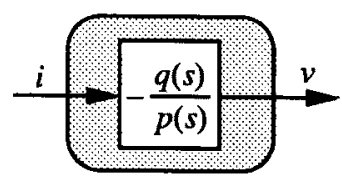

(e) Position sensorless feedback

図 3 ゼロパワーコントローラの一般形

(電圧制御形磁気浮上の場合)

Fig.3. General forms of zero-power controllers for the voltage-controlled magnetic suspension system. 
閉ループ系の極を任意に配置するためには，

$$
2 r \geq r+3 \quad \therefore r \geq 3 \text {, }
$$

すなわち， 3 次以上の次数を持つコントローラが必要とな る. 最も低次のものを用いる場合, 式(29)はつぎのように表 される.

$$
V(s)=-\frac{s\left(n_{3} s^{2}+n_{2} s+n_{1}\right)}{s^{3}+m_{2} s^{2}+m_{1} s+m_{0}} X(s)
$$

式(3)，(4)，(31)から，閉ループ系の特性多項式が次式のよ うに求められる.

$$
\begin{aligned}
\bar{t}_{c}(s)= & s^{6}+\left(c_{0}+m_{2}\right) s^{5}+\left(-a_{0}+c_{0} m_{2}+m_{1}\right) s^{4} \\
& +\left(a_{0} c_{0}+b_{0} d_{0}-a_{0} m_{2}+c_{0} m_{1}+m_{0}+b_{0} e_{0} n_{3}\right) s^{3} \\
& +\left(\left(a_{0} c_{0}+b_{0} d_{0}\right) m_{2}-a_{0} m_{1}+c_{0} m_{0}+b_{0} e_{0} n_{2}\right) s^{2} \\
& +\left(\left(a_{0} c_{0}+b_{0} d_{0}\right) m_{1}-a_{0} m_{0}+b_{0} e_{0} n_{1}\right) s \\
& +\left(a_{0} c_{0}+b_{0} d_{0}\right) m_{0}
\end{aligned}
$$

ここで,

$$
c_{0}=\frac{R}{L}, \quad d_{0}=\frac{k_{b}}{L}, \quad e_{0}=\frac{1}{L} .
$$

配置したい極を指定する多項式 $\bar{t}_{d}(s)$ を次のようにおく．

$$
\bar{t}_{d}(s)=\prod_{i=1}^{3}\left(s^{2}+2 \zeta_{i} \omega_{i} s+{\omega_{i}}^{2}\right)
$$

式(32)と式(33)とを比較すると，ゼロパワー制御を達成する と同時に，望ましい極配置を実現するコントローラの係数 が求められる.

\section{5. 実験}

5.1 実検装置実験には, 図 4 に示す装置を用いた. 浮上 対象物となるアームは，一端を玉軸受で支持されており， 鉛直面内を回転運動する．磁気浮上用の電磁石は, アーム の上部に設置されている. ゼロパワー浮上用の永久磁石は, 浮上対象物側の鉄心に組込まれている。 このような構成之 すると, コイルを流れる電流の向きによって, 吸引力だけ ではなく，反発力も働くようにすることができるので，電 磁石側に永久磁石を組込んだ場合に比べて動作範囲が広く なる.

アームの運動は, 渦電流形変位センサによって検出した。 アームには, 外乱発生用のボイスコイルモータの可動部を 取り付けた，また，アームが電磁石やセンサと接触するの を防ぐため, ストッパーによってアームの動きを拘束した。

制御系の実装には，ディジタルコントローラ（dSPACE 社 DS1103）を用いた．離散化は，伝達関数と等価な状態空間 モデルを求め, それを零次ホールド近似することによって 行った.また，制御周期は $100[\mu \mathrm{sec}]$ とした。

表 1 に実験装置の諸元を示す.

5.2 電流制御形についての実検結果実験では, 電流を流 したときに浮上体が電磁石から離れるようにストッパーの
位置を調節し, 浮上対象物がストッパーに接触している状 態から制御を開始した。

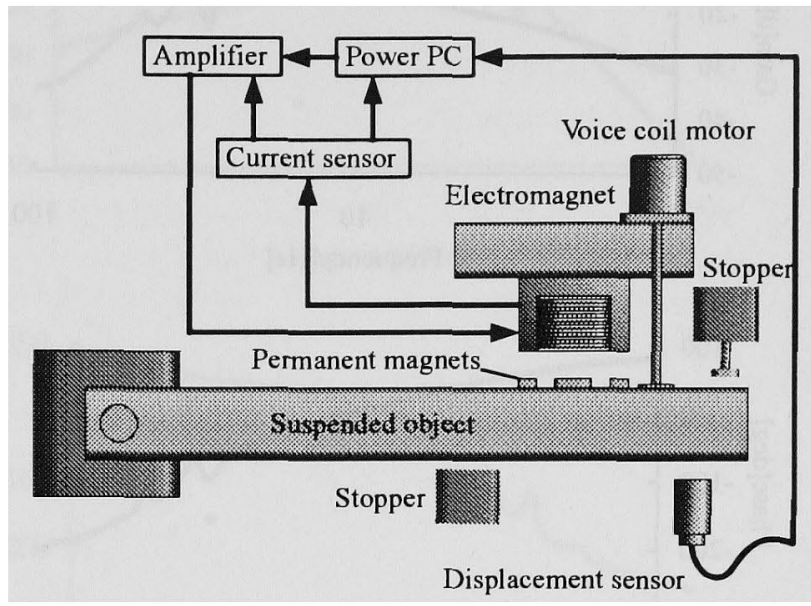

図 4 実験装置

Fig.4. Experimental apparatus

\section{表 1 実験装置の諸元}

Table.1. Parameters of the experimental apparatus

\begin{tabular}{cc|cc}
\hline$a_{0}$ & $4.6 \times 10^{3} \mathrm{~N} / \mathrm{kg} \cdot \mathrm{m}$ & $R$ & $8.5 \Omega$ \\
\hline$b_{0}$ & $7.0 \mathrm{~N} / \mathrm{kg} \cdot \mathrm{A}$ & $L$ & $130 \mathrm{mH}$ \\
\hline & & $k_{b}$ & $60 \mathrm{~V} / \mathrm{m}$ \\
\hline
\end{tabular}
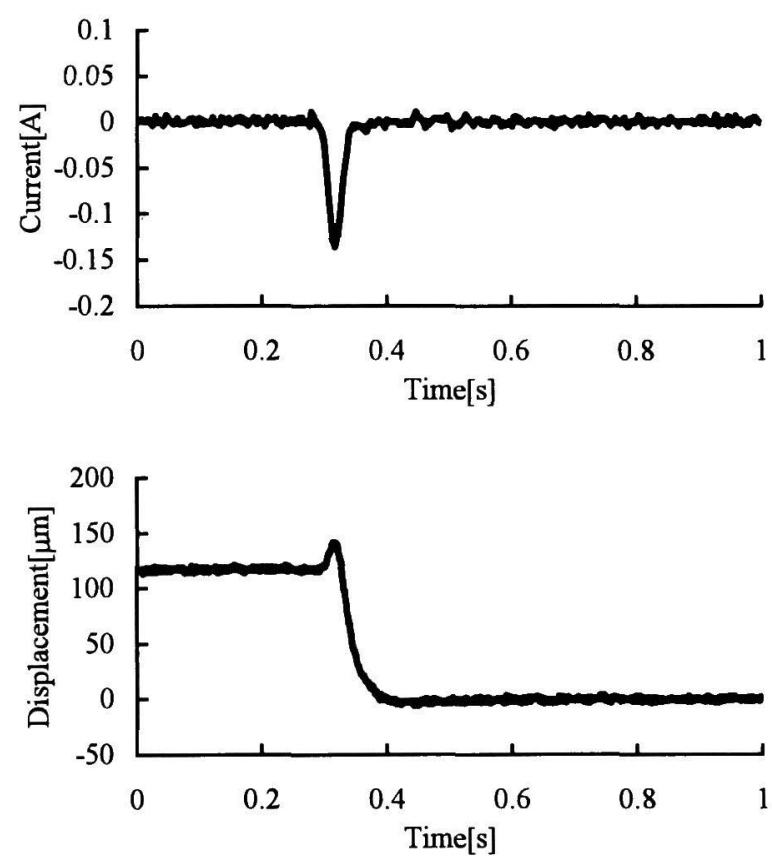

図 5 電流制御形ぜロパワー磁気浮上系のステップ応答

Fig.5. Step response of a current-controlled magnetic suspension system under zero-power control 

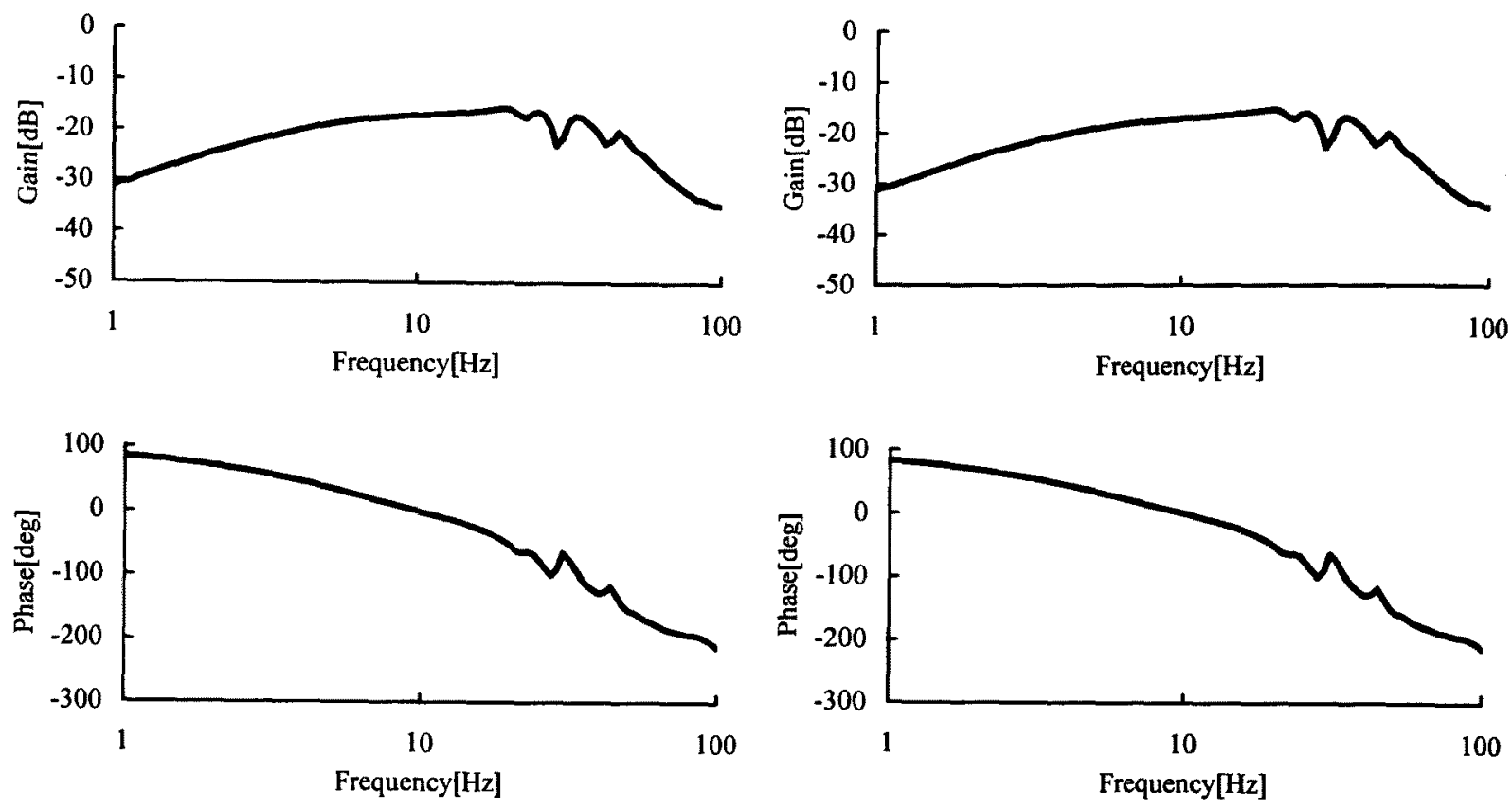

(a) Derivative feedback of displacement

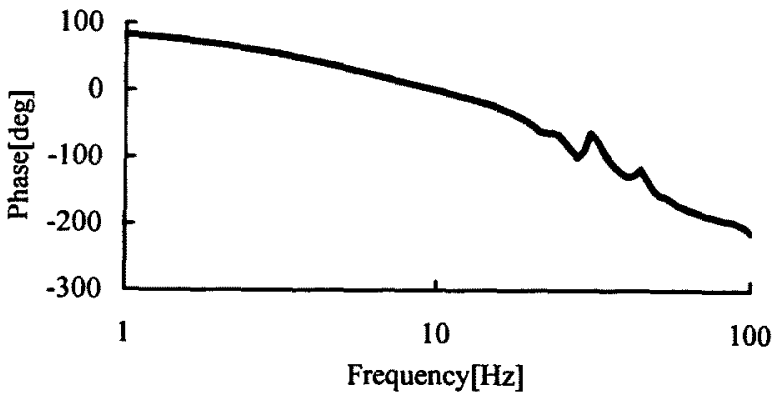

(b) Integral feedback of current

図 6 電流制御形ゼロパワー磁気浮上系の周波数店答

Fig.6. Frequency responses of zero-power control systems with a current-output power amplifier

最初に，図 2 (a)に構成を示すコントローラを用いた場合 のステップ外乱に対する応答を図 5 に示す。閉ループ系の 極は,

$$
\begin{array}{ll}
\omega_{1}=2 \pi \times 15(1 / s), & \zeta_{1}=0.7, \\
\omega_{2}=2 \pi \times 15(1 / s), & \zeta_{2}=0.7 .
\end{array}
$$

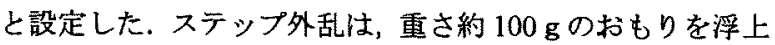
対象物に取り付け，それを $t \cong 0.3$ の時点で瞬時に取り除く ことによって発生させた．図 5 から，電流が定常的には零 に収束すると共に，重量が軽くなったため定常的な浮上位 置が下向き（ギャップが広くなる方向）に移動しているこ とがわかる。

つぎに、コントローラの構成を図 $2(a)$ （b)に示すように した各々の場合について，外乱に対する周波数応答を測定 した結果を図 6 に示す，入力信号は，浮上対象物に作用す るボイスコイルモータによって生成される外力, 出力信号 は，電磁石のコイル電流である，図から，二つの制御系は ほとんど同じ周波数特性を持っていることがわかる。した がって，コントローラの内部構成には依らず，同一の閉ル 一プ特性が実現されていることが寒証された。

5.3 電压制御形についての赛路耧果以下では, 変位信号 だけをフィードバック制御に用いるコントローラについて， 電流制御形と同様な実験を行った結果を示寸，図 7 は，図 $3(\mathrm{a})$ に構成を示すコントローラにおいて, $P(s)=0$ として，

閉ループ系の極を

$$
\omega_{1}=2 \pi \times 15(1 / s), \quad \zeta_{1}=0.7,
$$
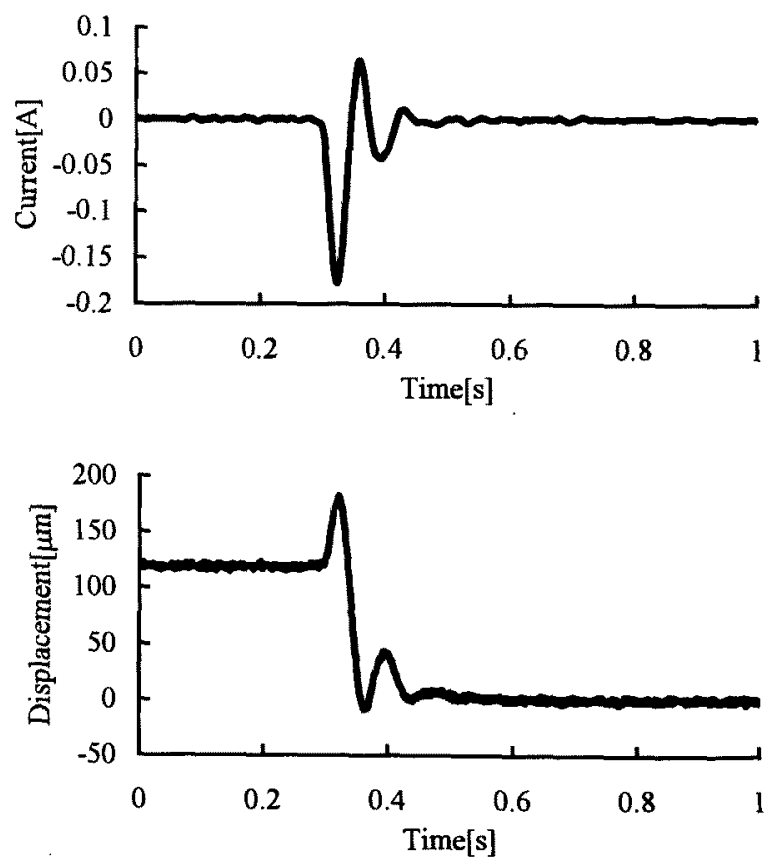

図 7 電在制御形ゼロパワー磁気浮上系のステップ応答

Fig.7. Step response of a voltage-controlled magnetic suspension system under zero-power control

$$
\begin{array}{ll}
\omega_{2}=2 \pi \times 15(1 / s), & \zeta_{2}=0.7, \\
\omega_{3}=2 \pi \times 15(1 / s), & \zeta_{3}=0.7 .
\end{array}
$$

と設定した系の外乱に対するステップ応答を示している. 

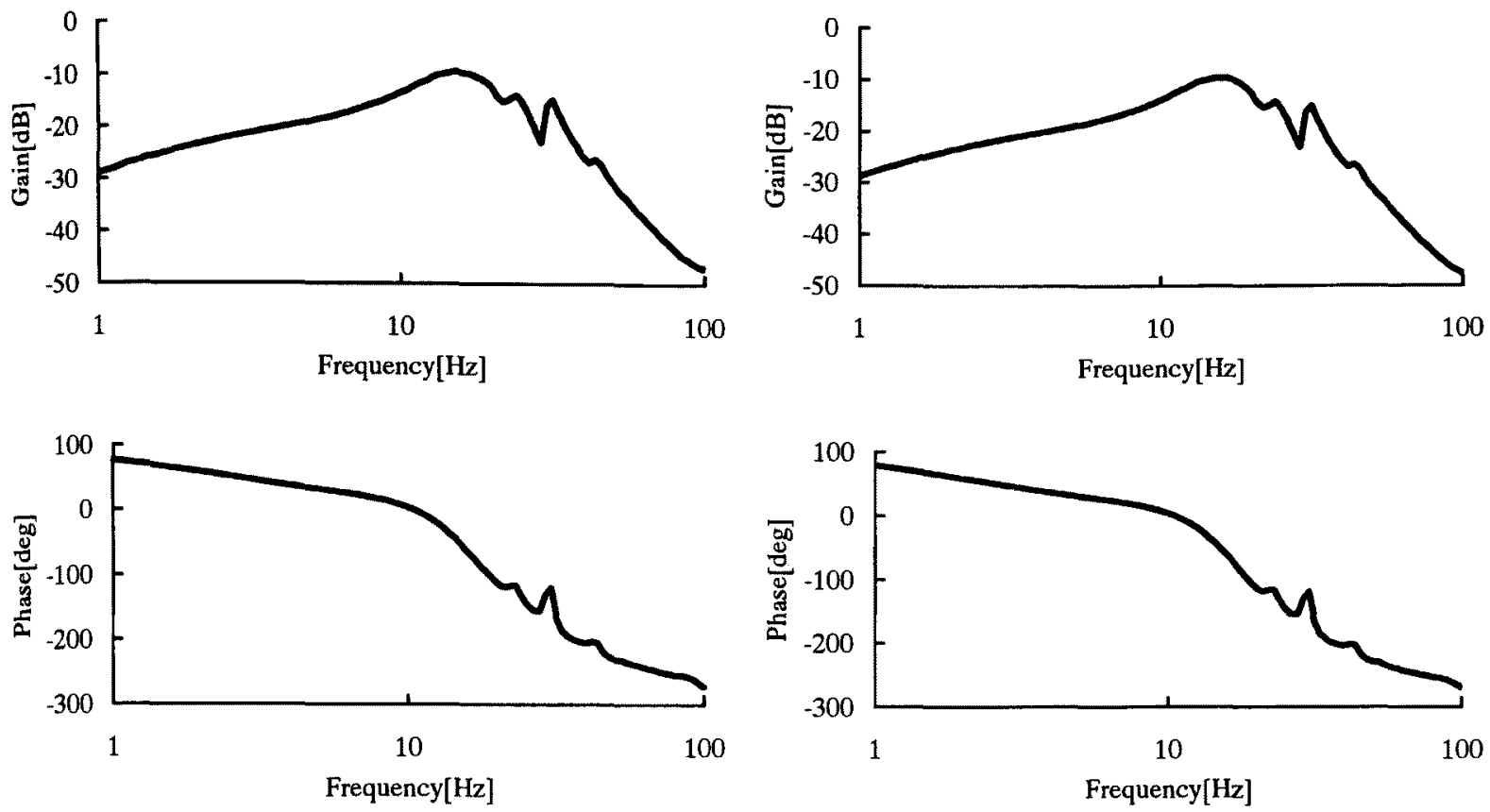

(a) Derivative feedback of displacement

(b) Integral feedback of voltage

図 8 電圧制御形ゼロパワ一磁気浮上系の周波数応答

Fig.8. Frequency responses of zero-power control systems with a voltage-output power amplifier

図から，ぜロパワー特性が奏現されていることが確認でき る.つぎに、コントローラの構成を図 3(a), (c)に示すよう にした各々の場合について，外乱に対する周波数応答を測 定した結果を図 8 に示す，図から，二つの制御系はほとん ど同じ周波数特性を持っていることがわかる. したがって， 電流制御形の場合と同様に，コントローラの内部構成には 依らず，同一の閉ループ特性が実現されていることがわか る.

\section{6. 結 言}

電流制御形および電圧制御形磁気浮上系のそれぞれに対 して，ゼロパワー制御を実現するコントローラの一般的な 構成を示した. 電流制御形磁気浮上系では, 変位の微分信 号に基づいてフィードバックする, 電流の積分值を局所フ イードバックするという二つの方式があるが，これらの方 式は電圧制御型磁気浮上系にも適用できる，また，後者に おいて，電流フィードバックだけを用いた制御采（変位セ ンサレス磁気浮上系）が自動的にゼロパワー特性を有する 条件を満たしていることを示した。ささらに，解析結果に基 ついて、コントローラを直接構成していく制御系設計法を 提案した。

実験では，解析と制御系設計法の有効性を検証するため， 電流制御形・電圧制御形磁気浮上のそれぞれについて設計 されたコントローラを実装し，外乱に対する応答を調べた。 その結果，提案する制御系設計法によってぜロパワー磁気
浮上を達成できることが確認された。 また，異なる構成を 持つコントローラの等価性が実証された。

制御系設計の箅所でも述べたが，電圧制御形磁気浮上采 の場合には，変位フィードバックと電流フィードバックの 組み合わせ方によっていろいろな実現方法が可能となる。 現在，各方法と構成された閉ループ系のロバスト性との関 保について検討を行っている。

(平成 12 年 10 月 30 日受付，同 13 年 3 月 26 日再受付)

\section{文薪}

(1) Henrikson, C. H., Lyman, J. and Studer, P. A., Magnetically Suspended Momentum Wheels for Spacecraft Stabilization, ALAA paper 74-128 (1974).

(2) Poubeau, P., Baudry, J. P. and Robinson, A.: Satellite Momentum and Reaction Wheels with Magnetic Bearings, Proc. AOCS, 375-379 (1977)

(3) Sabnis, A. V., Dendy, J.B. and F. M. Schmitt, A Magnetically Suspended Large Momentum Wheel, J. Spacecraft, Vol.12, pp.420-427 (1975).

(4) Morishita, M., Azukizawa, T., Kanda, S., Tamura, N. and Yokoyama, T., A New Maglev System for Magnetically Levitated Carrier System, IEEE Trans. Vehicular Technology, Vol.38, No.4, pp.230-236 (1989)

（5）水野：ゼロパワー磁気浮上機構を利用した除振装置の 開発（第 1 報: 基本構想)，第 39 回 SICE 学術講演会予 
稿集 304 C-5 (2000)

（6）森下, 小豆沢 : 常電導吸引式磁気浮上系のゼロパワー 制御, 電気学会論文誌 D, 108 巻, 5 号, pp.447-454 (1988).

(7) Yakushi, K., Koseki, T. and Sone, S., 3 Degree-of-Freedom Zero Power Magnetic Levitation Control by a 4-Pole Type Electromagnet, Proc. IPEC-Tokyo 2000, pp.2136-2141 (2000).

(8) Mizuno, T. and Bleuler, H., Self-Sensing Magnetic Bearing Control System Design Using the Geometric Approach, Control Engineering Practice, Vol.3, No.7, pp.925-932 (1995).

（9）水野: 伝達関数を用いた磁気軸受制御系の基本構造の 解析, 日本機械学会論文集 ( C 編)，65 巻, 637 号, pp.3507-3514 (1999).

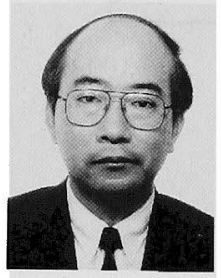

水野媇 （正員） 1956 年 3 月 18 日生. 1980 年 3 月東京大学大学院修士 課程修了. 同年東京大学生産技術研究所 助手. 1985 年職業訓練大学校講師. 1987 年埼玉大学工学部助教授. 2000 年同教授, 現在に至る。磁気浮上・磁気軸受, 振動 制御, 質量測定などの研究に従事. 工博.

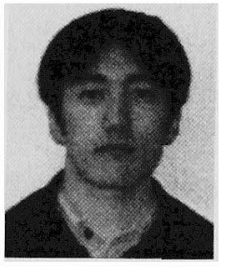

竹森 祐一郎 （非会員） 1976 年 12 月 16 日生. 1999 年 3 月埼玉大学工学部 機械工学科卒業. 2001 年 3 月埼玉大学大 学院理工学研究科機械工学専攻博士前期 課程修了. 2001 年 4 月（株）本田技研工 業入社, 現在に至る，在学中は, 磁気浮 上の研究に従事. 